\title{
Moderation of abortion debate
}

The chairman of the US Republican Party is not the most familiar source of wisdom on abortion, but everybody will benefit from what Mr Lee Attwater has learned in this month's elections in the United States.

THE months ahead may see a marked attenuation of the public rows about the practice of legitimate abortion. That, at least, seems to be one of the portents of this month's elections in the United States, when New York elected its first black mayor, when governorships were up for grabs in states such as New Jersey and Virginia and when several candidates for less exalted offices discovered, against expectation, that a strong anti-abortion platform could be an electoral disadvantage. The shift was marked enough for $\mathrm{Mr}$ Lee Attwater, the chairman of the Republican National Party proclaim that his party is a tolerant party that welcomes a variety of opinions, even on matters as contentious as abortion. Most of the anti-abortionists disappointed at the polls appear to be Republicans.

That abortion is a contentious issue, and will remain so, requires no explanation. Whatever the resolution of the tediously familiar argument about the point at which human life begins (conception, implantation, the emergence of the neural crest or the like), there is no doubt that the majority of fetuses now aborted are alive by almost any criterion. That is why, where abortion is permitted (in the United States, abortion is the prerogative of state governments, but the Supreme Court could change that), explicit conditions must be satisfied before an abortion can be carried out. The general principle derives from the notion that if, at childbirth, there is a choice between the survival of the mother and of the child, the mother's life takes precedence. To be able to demonstrate, say by amniocentesis, that a fetus is genetically handicapped is not by itself a sufficient cause for legalized abortion; in principle, at least, it is necessary for a woman seeking an abortion also to demonstrate that the birth of such a child will be damaging to her, if not physically then psychologically.

Opponents of abortion are of three kinds: those who call abortion murder whatever the circumstances, those who complain that the conditions that must be satisfied before an abortion may be legally carried out are insufficiently stringent and those who complain that the preconditions are so loosely applied that legal abortion is elective abortion. The arguments for legalized abortion, in similar order of increasing moderation, are that a woman's body (and whatever is inside it) is at her own disposal (the feminist view), that unwanted children are genuinely damaging and that legal but regulated abor- tion is preferable to illicit practice on a similar scale. In an ideal world, governments would seek to blunt unresolved argument by diminishing the scale of the problem by post-abortion counselling and easier access to birthcontrol clinics, but these measures are not popular with extremists. Until this month's elections, this seemed to matter to politicians. It may be less important now.

This journal has no brief to grind an axe on the abortion issue proper and does not do so, but there are several related issues that affect what happens in laboratories. In the United States, the Secretary of Health and Human Services has just extended a moratorium on the use of fetal tissue in transplants out of - it now seems - misplaced respect for anti-abortion forces (see Nature 342, 105; 1989). In Britain, the government's bill to regulate embryo research due to be published this week will be a vehicle for a parliamentary battle on abortion. But everywhere even those content with the legislation on abortion that may be in force should be concerned that its extreme opponents ('right-to-life' or 'abortion rights', as the case may be) are implacably opposed. It cannot much benefit grown-up societies that there should be apparently irreconcilable conflicts over the propriety of the law.

Despite a long history of bitter dispute, there is a chance that the two sides will be able to reach an accommodation with each other. That does not require that conflict should vanish overnight, but merely that people who are implacably opposed should learn that the other side has a case, but perhaps not the whole of what the extremists claim. Attwater may not be the most likely source of good sense on abortion, but his plea for tolerance deserves a hearing.

\section{Brain drain in flood}

Migrations of skilled Europeans in the past few weeks are only the beginning. Employers should respond.

BY the end of 1989 , the numbers of people who will have moved permanently from one country to another will be a record for recent times. Even before the East German frontier with the West was opened last week, some 50,000 people had made their way around it in the previous two months. That exceeds, but not by much, the numbers who will have left the Republic of Ireland (mostly for the 